\title{
Thermosensitive nanocomposite hydrogel based pluronic-grafted gelatin and nanocurcumin for enhancing burn healing
}

\author{
Huynh Thi Ngoc Trinh, Nguyen Tien Thinh, Ha Le Bao Tran, \\ Vu Nguyen Doan, Tran Ngoc Quyen
}

\begin{abstract}
Curcumin is extracted from turmeric exhibiting several biomedical activities. Unfortunately, less aqueous solubility was still a drawback to apply it in medicine. This study introduced a method to produce a thermosensitive nanocomposite hydrogel (nCur-PG) containing curcumin nanoparticles (nCur) which can overcome the poor dissolution of curcumin. Regarding to the method, a thermo-reversible pluronic F127-grafted gelatin (PG) play a role as surfactant to disperse and protect nanocurcumin from aggregation. The synthetic PG was identified by ${ }^{1}$ H-NMR. The obtained results via Transmission Electron Microscopy (TEM) and Dynamic Light Scattering (DLS) indicated that the size of nCur was various in the range from $1.5 \pm 0.5$ to $128 \pm 9.7 \mathrm{~nm}$ belong to amount of the fed curcurmin. The nCur-dispersed PG solution formed nCur-PG when the solution was warmed up to $34-35{ }^{\circ} \mathrm{C}$. Release profile indicated sustainable release of curcumin from hydrogel. Thermosensitive nanocomposite hydrogel based pluronic-grafted gelatin and nanocurcumin performed potential application of the biomaterial in tissue regeneration.
\end{abstract}

Index Terms-Nanocurcumin, milling method, Gelatin, pluronic F127, nanocomposite hydrogel, medicine

Received: 29-05-2017; Accepted:10-12-2017 ; Published: 15-10-2018.

Author: Huynh Thi Ngoc Trinh ${ }^{1, *}$, Nguyen Tien Thinh ${ }^{1}, \mathrm{Ha}$ Le Bao Tran ${ }^{2}$, Vu Nguyen Doan ${ }^{2}$, Tran Ngoc Quyen ${ }^{1,3}$ ${ }^{1}$ TraVinh University, ${ }^{2}$ Institute of Applied Materials Science, Vietnam Academy of Science and Technology (VAST), ${ }^{3}$ University of Science, VNUHCM

(email: htntrinh99@tvu.edu.vn)

\section{INTRODUCTION}

$\mathrm{R}$ ecent years, exploitation of naturally bioactive compounds has paid much attention in medicine due to their broad-spectrum bioactivity such as anti-inflammation, antioxidation, anticancer, wound healing and etc [1]. Among of them, curcumin (1,7-bis (4-hydroxy3-methoxyphenyl)- 1,6-heptadiene-3,5-dione) isolated from rhizome of Curcuma longa plant exhibiting desirable pharmaceutical properties including anti-inflammatory [2-3], antioxidant [4-5], anti-tumor [6], anti-HIV [7], antimicrobial activity [8-9], and wound healing agent [10]. Despite its attractive pharmaceutical characteristics, low aqueous solubility, poor bioavailability, rapid metabolism due to the firstpass metabolism [11-13] hampered curcumin in the journey of wider medical application. Nanotechnology has been approaching as an effective solution to improve the bioavailability of the lipophilic compounds. Nano-formulated platforms like liposome, micelle, polymeric nanoparticle and solid lipids have elevated the therapeutic effects of the hydrophobic drugs [14]. It is reported that the nano-scaled curcumin enhanced the dissolution rate [15]. Moreover, the loaded curcumin could protect it from enzymatic degradation, enhance water-solubility and duration blood circulation [16]. Among the mentioned platform, amphiphilic block copolymers-based micelles are able to selfassemble for core-shell architecture loading nanocurcumin. The hydrophobic core is the main part for encapsulation curcumin in order to improve the aqueous solubility. Sahu et al [17] 
was reported that Pluronic micelle could effectively delivery curcumin for inhibiting Hela cancer cell growth. Pluronic F127 (Poloxamer 407) is the thermo-inducible tri-block copolymer of hydrophilic (poly(ethelene oxide) and lipophilic P (poly(propylene oxide), with general formula $\mathrm{E}_{107} \mathrm{P}_{70} \mathrm{E}_{107}$. The thermo-reversible behavior of copolymer platform performed sol at $4{ }^{\circ} \mathrm{C}$ and gel at physiological temperature which can be the micelle-vesicle for curcumin-encapsupation. However, the pluronic-based materials were general bio-inert so some derivatives were developed to improve its biological interaction [1819].

The conjugation with gelatin could enhance its biocompatibility of thermo-responsible hydrogel solution. Moreover, it could be expected to increase the interaction between nanocurcumin (partial negative charge) and the PG copolymer backbone (partial positive charge) resulting in enhancing the drug loading efficiency and its dispersion.

In this present study, we aim to prepare the thermo-responsive PG copolymer and ultilize it as the dispersant platform for fabricating nanocurcumin in the thermosensitive PG copolymer solution under the assisted sonication. The thermo-sensitive nanocomposite hydrogel was applied to enhance the second degree burn healing.

\section{MATERIALS AND METHODS}

\section{Materials}

Porcine gelatin (bloom 300), pluronic F127 and curcumin (Cur) were purchased from Sigma Aldrich (St. Louis, USA). Mono $p$ nitrophenylchloroformate-activated pluronic (NPC$\mathrm{P}-\mathrm{OH}$ ) was prepared in our previous study (Nguyen el al. 2016; Nguyen et al. 2017). Diethyl ether was obtained from Scharlau's Chemicals (Spain), THF tetrahydrofuran (THF) was purchased from Merck (Germany), and dialysis membranes (MWCO 14 $\mathrm{kDa}$ and MWCO $3.5 \mathrm{kDa}$ cut-off) were supplied from Spectrum Labs (USA),). PBS buffer is analytical grade.

\section{Synthesis of PG copolymer}

In a round flask, gelatin (1 gram) was dissolved in DI water. An aqueous NPC-P-OH $(15 \mathrm{~g})$ solution was added drop-wise to the flask at $20^{\circ} \mathrm{C}$ under stirring overnight. After the time, the mixture was dialyzed against distilled water for 3 days using cellulose membrane (MWCO 14 $\mathrm{kDa}$ ) and lyophilized to have a powder as a thermo-sensitive copolymer platform for further study. The copolymer was characterized with ${ }^{1} \mathrm{H}$ NMR on Bruker AC spectrometer (USA).

PG copolymer was synthesized via a threestep process as show in fig. 1 .

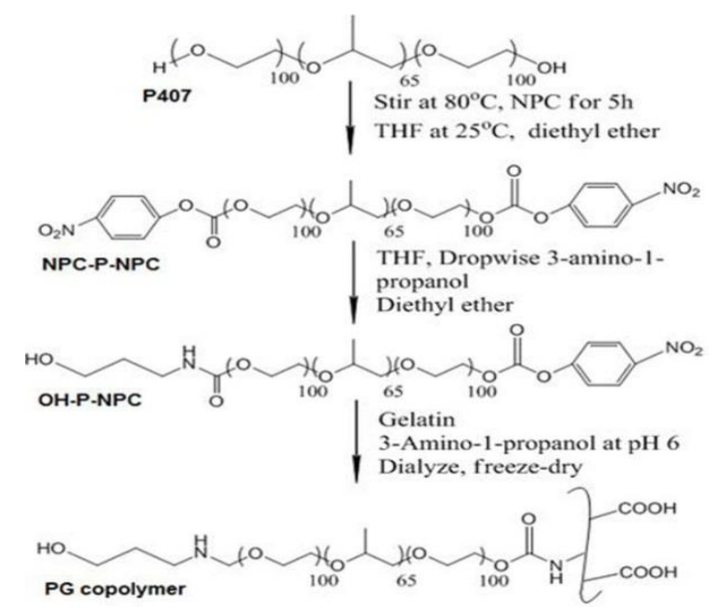

Fig. 1. Synthetic scheme of PG copolymer

\section{Sol-gel transition behavior}

$0.5 \mathrm{~mL}$ aqueous copolymer solutions were prepared from varying PG (ratio of $\mathrm{G}: \mathrm{P}=1: 10$, 1:15 and $1: 20 \mathrm{wt} / \mathrm{wt})$ at $20{ }^{\circ} \mathrm{C}$. The designated range temperature was set up at $(4,25,30,37,40$ and $50{ }^{\circ} \mathrm{C}$ ) to determine the sol-gel transition behavior of nanocomposite hydrogel using the test tube inversion method which could observe the "flow as the liquid solution" or "no flow as the gel formation". A sol-gel phase diagram was built regarding to the recorded data.

\section{Fabrication of nCur-dispersed PG copolymer and its NCur-PG form}

$2.5 \mathrm{mg}$ curcumin was dissolved in $5 \mathrm{~mL}$ absolute ethanol under sonication. The suspension was added drop-wise to the PG copolymer solution $(500 \mathrm{mg}$ PG in $2.5 \mathrm{~mL}$ DI water and $5 \mathrm{~mL}$ ethanol). Then ethanol solvent 
was evaporated by the rotary evaporator to obtain a homogeneous nCur-loaded PG paste form and cold DI water was added to obtain thermosensitive nCur-dispersed PG copolymer solution (as shown in Fig. 2) that could be transfered into nCur-PG at warming condition. Morphology of nCur was observed by TEM (JEM-1400 JEOL) at $25{ }^{\circ} \mathrm{C}$. Spectral analysis was observed by UV-Vis spectroscopy (Agilent $8453 \quad$ UV-Vis Spectrophotometer) at $420 \mathrm{~nm}$ wavelength. Particle size distribution was determined using dynamic light scattering (DLS).

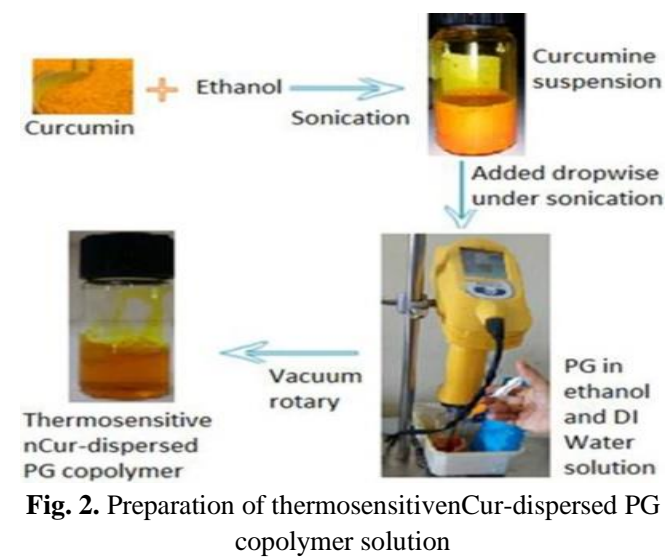

\section{Release study}

In the study, a diffusion method with dialysis membrane was used to investigate the in vitro release of Cur from the nCur-loaded composite hydrogel that was prepared from $1 \mathrm{~mL}$ of copolymer $(20 \% \mathrm{w} / \mathrm{v})$ containing $2.5 \mathrm{mg}$ nCur. The dialysis bag (MWCO $3.5 \mathrm{kDa}$ ) containing $2 \mathrm{~mL}$ sample was immersed in $10 \mathrm{~mL}$ phosphatebuffered saline (PBS) which had been put over a period of 24 hours maintained at $37{ }^{\circ} \mathrm{C} \pm 0.5^{\circ} \mathrm{C}$ in a water bath. The Cur content was quantified by the Foresaid Agilent 8453 UV-Vis Spectrophotometer. The release experiments were performed in triplicate with $95 \%$ Confidence Interval. The cumulative release of drug was performed from equation [20].

$$
\mathrm{Q}=\mathrm{C}_{\mathrm{n}} \mathrm{V}_{\mathrm{t}}+\mathrm{V}_{\mathrm{s}} \sum \mathrm{C}_{\mathrm{n}-1}
$$

Where $\mathrm{Cn}$ represented the concentration of drug in sample, $\mathrm{Cn}-1$ was release concentration at $\mathrm{t}$, Vt was the incubated medium and Vs was volume of replaced medium.

\section{Wound healing testing on animal model}

Animals: Healthy adult male Mus musculus var. Albino mice (33-42 g, $\mathrm{n}=6$ ) were procured from the Pasteur Hospital, Ho Chi Minh City, Vietnam. Mice were maintained in standard laboratory conditions with add libitum accessto feed and water, light-dark cycle and adequate ventilation.

Wound creation: The experiment was conducted at Laboratory of Department of Physiology and Animal Biotechnology under the permission of the Animal Care and Use Committee of the University of Science, Vietnam National University Ho Chi Minh City (Registration No. 10/16-010-00), Vietnam. The mice were anesthetized by intraperitoneal ketamine $(100 \mathrm{mg} / \mathrm{mL})$ and xylazine $(20 \mathrm{mg} / \mathrm{mL})$ injection with dosage of $0.2 \mathrm{~mL} / 100 \mathrm{~g}$ body weight. The dorsal skin of the animals was shaved and cleaned with $70 \%$ ethanol and $1 \%$ polyvinylpyrrolidone iodine. The secondary burn degree was created by a cylindrical stainless steel rod of $1 \mathrm{~cm}$ diameter previously heated in boiling water at $100{ }^{\circ} \mathrm{C}$. The rod is maintained in contact with the animal skin on the dorsal proximal region for $5 \mathrm{sec}$. Thereafter, medication was initiated for these four groups (nontreatment, dressing PG, nCur-PG copolymer (20 $\mathrm{w} / \mathrm{v} \%$ ) containing $2.5 \mathrm{mg} \mathrm{nCur}$ and commercial product/Biafine). Dressings were performed on each 2 days and finished on days 14. Each mouse contained two wounds (fig. 3), each medication was randomly assigned. A photograph of each wound was taken on days $0,2,6,8,12$ and 14 . Wound size was measured using Caliper (0-200 $\mathrm{mm}$ Mitutoyo 530-114). The area of wound contraction was calculated following the equation (Jia el al. 2007):

$$
\text { Area of wound }=\frac{\pi}{4} \times l_{i} \times w_{i}
$$

Where $l_{i}$ and $w_{i}$ represented for the length of wound surface at ith day post-wounding. 


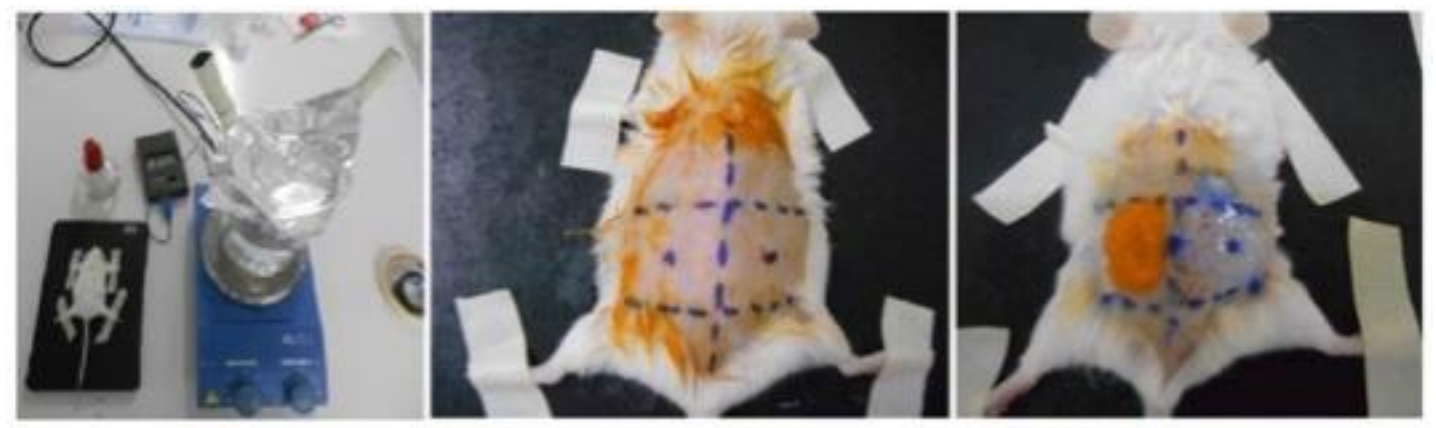

Fig. 3. Experimental design on animal model

Statistical analysis: Data were represented as means \pm standard error $(n=3)$. ANOVA two ways (SPPS software) was used for the analysis of cytotoxicity on fibroblast cells and wound contraction. A p-value $<0.05$ was accepted as a statistically significant difference.

\section{RESULTS AND DISCUSSION \\ Characterization of copolymers}

${ }^{1} \mathrm{H}$ NMR spectrum of the activated NPC-PNPC appeared a prominent resonance peak at $\delta=$ 4.42 and two peaks at $7.38-8.22 \mathrm{ppm}$ that corresponded to the signal of protons on the terminal methylene $\left(-\mathrm{CH}_{2}-\mathrm{CH}_{2}-\right)$ in the activated plruronic and aromatic NPC protons, respectively. Activated degree of NPC-P-NPC was over 95\% $\left({ }^{1} \mathrm{H}\right.$ NMR). In spectrum of NPC-P-OH, one new peak at $\delta=4.22$ assigned to terminal methylene protons $\left(-\mathrm{CH}_{2}-\mathrm{CH}_{2}-\right)$ in the NPC-substituted moiety of the activated pluronic. These evidences confirmed that NPC-P-NPC and NPC-P-OH were successfully prepared (spectra not shown here) [22].

Pluronic-grafted gelatin (PG) was created via urethane linkage between amine groups on gelatin backbone and NPC-remaining moiety of NPC-P$\mathrm{OH}$. In the PG spectrum, the resonance peak at 7.23-7.29 ppm indicated aromatic protons of phenylalanine and other typical protons of aminoacids in gelatin as noted in fig. 4. Some protons of the pluronic $\left(-\mathrm{CH}_{3}\right.$ of $\mathrm{PPO}$ at $1.08 \mathrm{ppm}$ and $-\mathrm{CH}_{2}$ of $\mathrm{PEO}$ at $3.6 \mathrm{ppm}$ ) also appeared in the spectrum. Moreover, a disappearance of aromatic proton (NPC) at 7.38-8.22 ppm confirmed the substitution of NPC by the primary amine of gelatin to form PG copolymer.

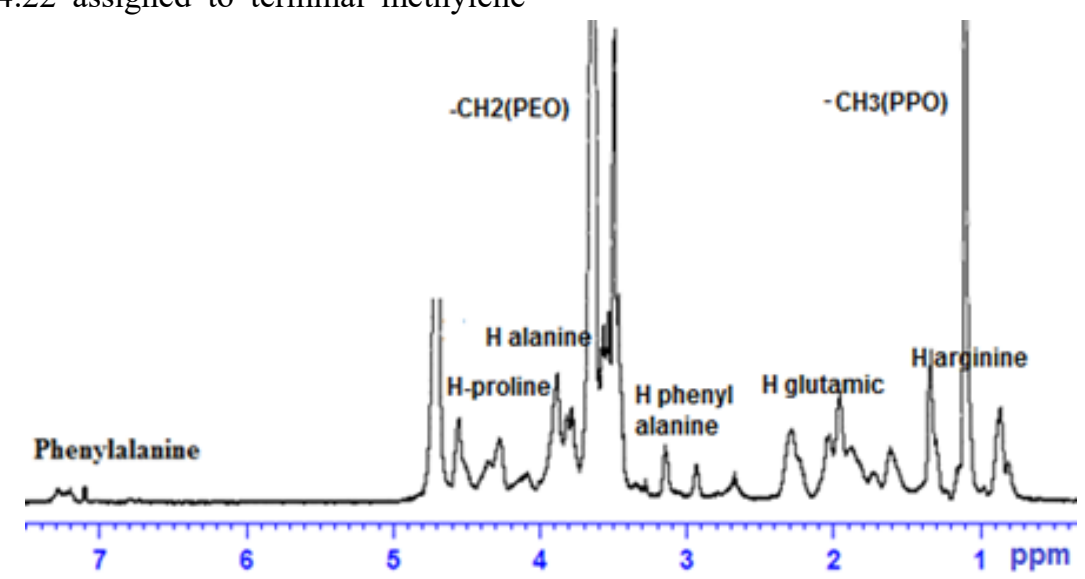

\section{Thermo-reversible behavior}

Fig. 4. 1H NMR spectrum of PG copolymer

Phase diagram of sol-gel transition behavior in Fig. 5 indicated the phase conversion of four samples of $\mathrm{PG}$, which were different in weight ratio of gelatin and pluronic (PG 1:5, PG 1:10, PG 1:15, PG 1:20). The gelation temperature depended on the ratio of pluronic grafted to gelatin. A lowest gelation temperature of PG 1:5 
was seen in the Fig. 5A, corresponding to the property of gelatin that formed gel at low temperature and dissolved at room temperature. As increasing content of pluronic in the grafted copolymer (PG 1:10, PG 1:15 and PG 1:20), the gelation behavior was partially followed to the thermal property of pluronic. For PG 1:10 sample, the gelation occurred when its concentration was higher $12.5 \%(\mathrm{wt} / \mathrm{v})$ at $30{ }^{\circ} \mathrm{C}$, but its physical property was weak. At a same temperature, PG 1:15 and PG 1:20 occurred gelation at lower concentration of PG copolymer (around 10\% (w/v)) and the formed gels were high stable at $15 \%(\mathrm{w} / \mathrm{v})$ of PG which could be used for further studies. The gel "phase" occurred due to hydrophobic effect [23, 24], attributed self-assembly and coil to helix converting for conformation altering caused the "solid-like gel" at critical micelle concentration under critical solution temperature. The sol-gel transition of the copolymer solution could be observed with DSC measurement as shown in Fig. 5B, in which maximally exothermic peak at $36.27{ }^{\circ} \mathrm{C}$ (ranging from 28 to $40{ }^{\circ} \mathrm{C}$ ) performed a solidification of the PG solution. The phase diagram also showsed that temperature ranges of the PG copolymer solution was a homogeneous phase. This behavior was near similar to a report from Barba A. A. et al [25] who investigated the sol-gel transition behavior of pluronic [25].
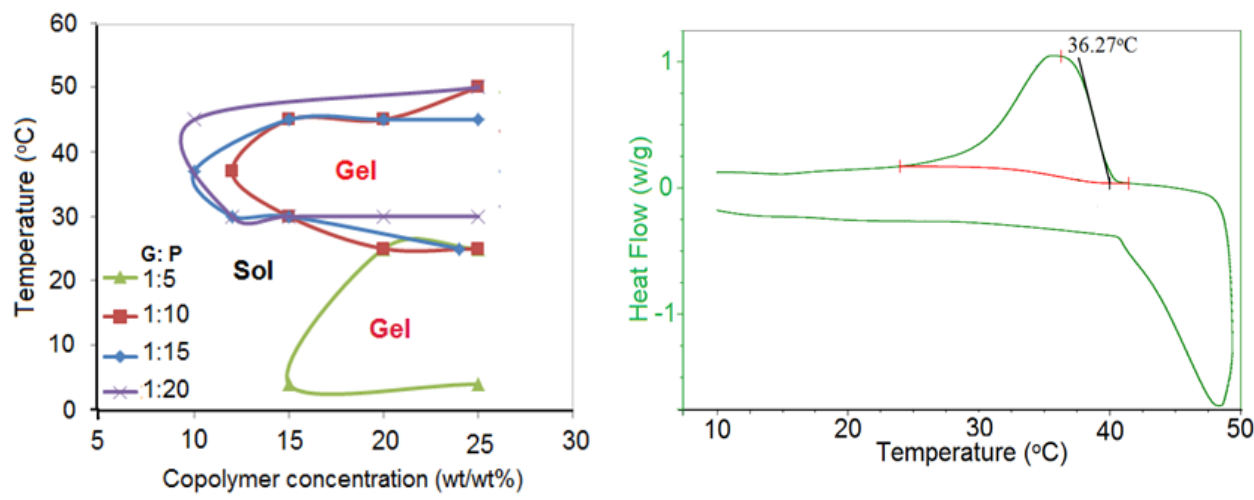

Fig. 5. A) Phase diagram of sol-gel transition behavior of PG copolymer solution, B) DSC signal recorded following heating/cooling process of solution at $15 \% \mathrm{wt} / \mathrm{v}$ of PG

\section{Characterization of the nanocurcumin- loaded thermogel}

Several reports indicated that nano-scaled curcumin could enhance the cellular absorption and biodistribution of the hydrophobic molecule [26]. So some methods have been introduced to formulate nanocurcumin such as ultrasonication, milling, using surfactant and etc. Our study used an ultrasonic and PG dispersant combination method to produce nanocurcumin suspension. It was more interesting that the nanosuspension solution could form the nanocomposite hydrogel when the suspension was warmed up (fig. 6). The nanocurcumin could form in the PG copolymer solution and the PG copolymer contributed to the stability the nanocurcuminin hydrophobic domain of PG [27]. Moreover, Zeta potential measurement showed the positively charged PG copolymer and the negatively charged nanocurcumin (data not shown here) which could offer a significant role of gelatin in enhancing stability of nanocurcumin due its electrostatic interaction. The effect of curcumin formulations on the size distribution of nanocurcumin were evaluated by TEM (fig. 7) and DLS (fig. 8) at $4{ }^{\circ} \mathrm{C}$ that indicated the size of the round-shaped nanocurcumin significantly varied ranging from 7 to $258 \mathrm{~nm}$ belonging to the amount of loaded curcurmin formulated with PG copolymer. DLS revealed that the hydrodynamic diameter of nanoparticles was a function of concentration. A higher concentration of the fed curcumin, afforded 
larger size diameter. The formed nanoparticles was $7 \pm 0.5 \mathrm{~nm}(5 \% \mathrm{wt} / \mathrm{wt}), 16 \pm 3.2 \mathrm{~nm}(10 \%$ wt/wt), $26 \pm 10.3 \mathrm{~nm}(15 \% \mathrm{wt} / \mathrm{wt}), 128 \pm 8.8 \mathrm{~nm}$ $(20 \% \mathrm{wt} / \mathrm{wt})$ and $258 \pm 9.7 \mathrm{~nm}(30 \% \mathrm{wt} / \mathrm{wt})$. In particularly, the incorporation of nanocurcumin did not affect the thermal-reversible behavior of PG responsible- hydrogel.

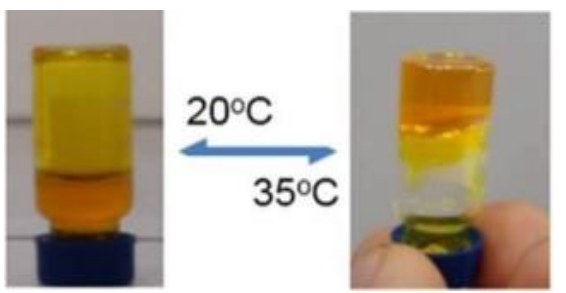

Fig. 6. Sol-gel transition of nCur-PG hydrogel

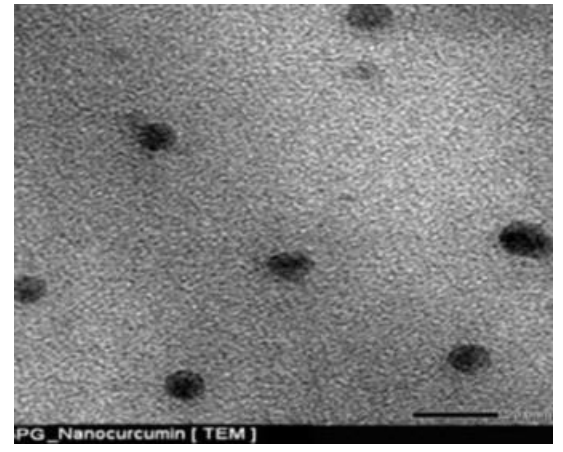

Fig. 7. TEM image of nanocurcumin dispersed in PG 1:15 with $5 \% \mathrm{wt} / \mathrm{wt}$ curcumin
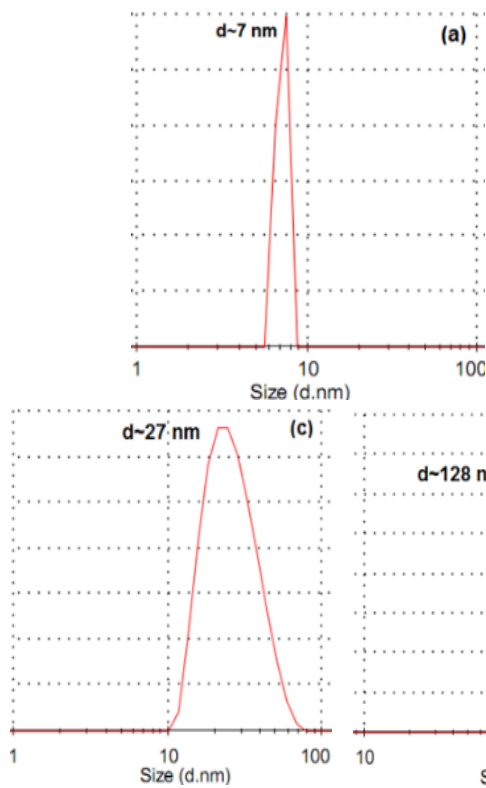
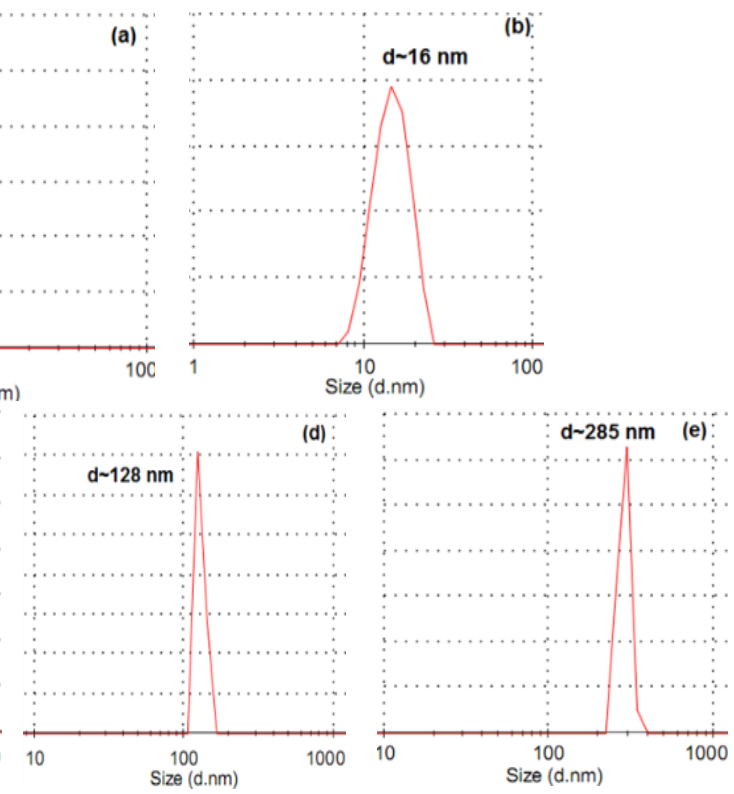

Fig. 8. Particle size distribution of nanocurcumin at different concentration with PG in solution of 5\% w/w (a), 10\% w/w (b), $15 \%$ w/w (c), $20 \%$ w/w (d), $30 \%$ w/w (e) 


\section{In vitro release study}

In order to investigate the controllable delivery manner of the thermosensitive nanocurcuminloaded PG platform, the in vitro release study was performed using a diffusion method with dialysis membrane. Fig. 9 depicts the release profile of nanocurcumin for 24 hours. In detail, for the first 2 hours only $5 \%$ drug released, whereas, curcumin delivery was for the later 3 hours reached up $50 \%$, subsequently exhibited a constant rate of release was $74.66 \pm 3.9 \%$. The graph elucidates the mediated nanocurcumin release fashion over time, provided the potential matrix for drug delivery to the site administration.

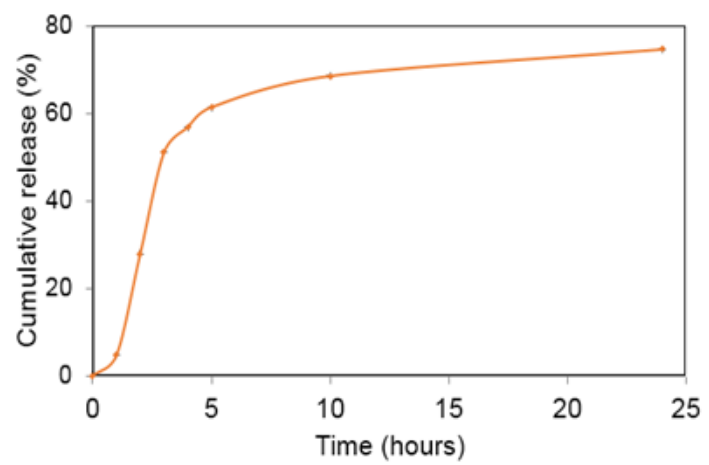

\section{Burn healing evaluation}

Fig. 10 indicated that the PG-treated wound exhibited a faster wound healing rate than that of control, but healing was slower than the rates observed in nCur-PG and commercial dressings. The nCur-PG model described that the wound recovery was faster than other groups. Macroscopically, the wounds were almost closed at 10 days, and appeared as scar tissues 14 days after treatment. There was no obviously difference in the speed of wound closure among the models during the 14 day follow-up period, except the non-treatment wounds with. After 14 days, only the group nCur-PG showed the new hair on wound surface and the similar skin color of other skin area on mice, while in non-treatment model, all wounds have epithelialized and a raised hypertrophic scar was visible. No hair on the wound surface or hypertrophic scar in the PG gel and commercial product-treated models. This obtained results suggested that the presentation of nanocurcumin accelerated the wound healing process. It was marked by wound area reduction and wound recovery.

Fig. 9. Release profile of nanocurcumin in Pggel

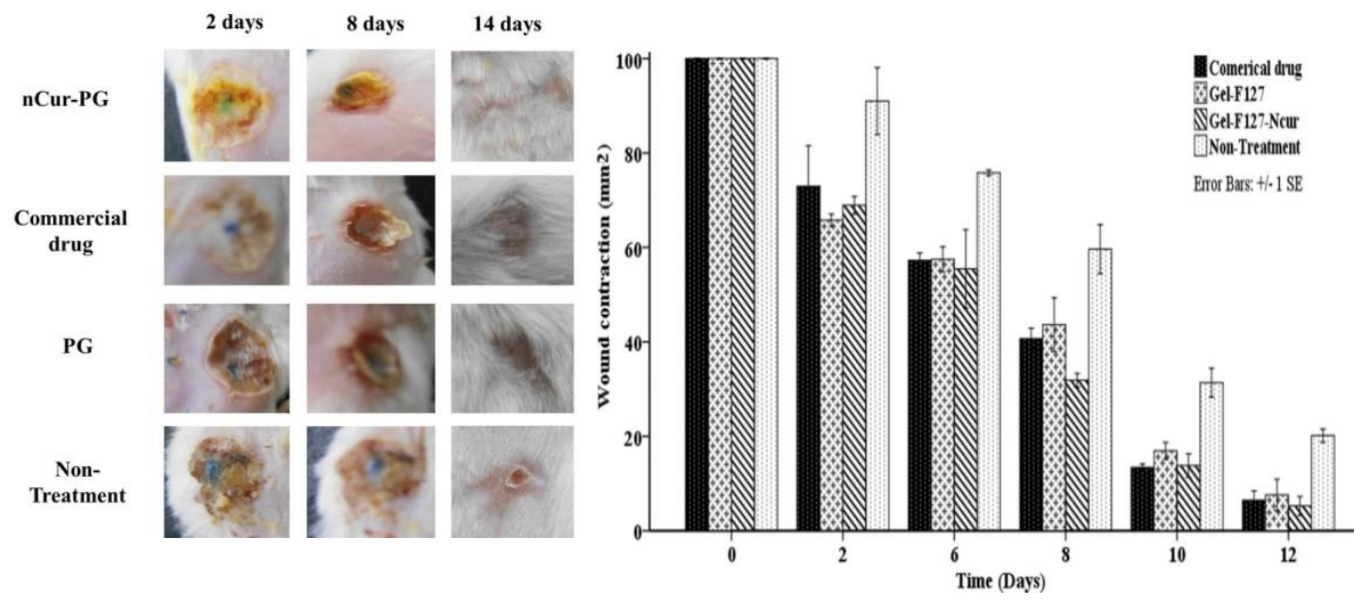

Fig. 10. Macroscopic image of wound surface in animal model at 2, 8 and 14 post treatment and wound contraction after 14 days. The error bar was presented by $+/-\mathrm{SE}$

\section{CONCLUSION}

We successfully synthesized a thermosensitive pluronic-grafted gelatin copolymer served as a dispersant to produce small size of nanocurcumin (lower than $20 \mathrm{~nm}$ ) or high nanocurcumin content (up to 30 $\mathrm{wt} / \mathrm{wt} \%$ ) with the feeded copolymer. The nCurdispersed PG copolymer solution could form a nanocomposite hydrogel at the physiological temperature (around $35{ }^{\circ} \mathrm{C}$ ). Sustainable release profile of curcumin from the hydrogel matrix 
provided the desirable vehicle to control the delivery of curcumin at a suitable concentration for enhancing wound healing (low concentration of encapsulated curcumin) or inbibiting the growth of cancer cell (high concentration of encapsulated curcumin). These obtained results could be pave a way to apply the thermosensitive nanocurcumin-loaded platform in biomedical field.

Acknowledgements: This work was financially supported by Tra Vinh University under Grant Number 1434/HD.DHTV-KHCN and Vietnam Academy of Science and Technology (VAST) under Grant Number VAST03.08/17-18.

\section{REFERENCES}

[1].G.C. Jagetia, B.B. Aggarwal, Spicing up of the immune system by curcumin, J. Clin. Immunol., 27, 1, 19-35, 2007.

[2].R.C. Srimal, B.N. Dhawan, Pharmacology of diferyloyl methane (curcumin), a non-steroidal antiinflammatory agent, J. Pharm. Pharmacol., 25, pp. 447-452, 1973.

[3].B.B. Aggarwal, K.B. Harikumar, Potential therapeutic effects of curcumin, the anti-inflammatory agent, against neurodegenerative, cardiovascular, pulmonary, metabolic, autoimmune and neoplastic diseases, Int $J$ Biochem Cell Biol, 41, 40-59, 2009.

[4].Y. Sugiyama, S. Kawakishi, T. Osawa, Involvement of the diketone moiety in theantioxidativemechanism of tetrahydrocurcumin, Biochem Pharmacol, 52, 519525, 1996.

[5].P. Pizzo, C. Scapin, M. Vitadello, C. Florean, L. Gorza, Grp94 acts as a mediator of curcumin-induced antioxidant defense in myogenic cells, J. Cell Mol. Med., 14, 970-81, 2010.

[6].Y.K. Lee, W.S. Lee, J.T. Hwang, D.Y. Kwon, Y.J. Surh, O.J. Park, "Curcumin exerts anti-differentiation effect through AMPKalpha-PPAR-gamma in 3T3-L1 adipocytes and antiproliferatory effect through AMPKalpha-COX-2 in cancer cells, J. Agric. Food Chem., vol. 57, pp. 305-10, 2009.

[7].W.C. Jordan, C.R. Drew, "Curcumin-A natural herb with anti-HIV activity", J. Natl. Med. Assoc., vol. 88, no.6, pp. 333-34, 1996.

[8].D. Ronita, K. Parag, S. Snehasikta, T. Ramamurthy, C. Abhijit, G.B. Nair, K.M. Asish, Antimicrobial activity of curcumin against Helicobacter pylori isolates from India and during infections in mice, Antimicrob Agents Chemother, 53, 4, 1592-97, 2009.

[9].Y. Wang, Z. Lu, H. Wu, F. Lv, Study on the antibiotic activity of microcapsule curcumin against foodborne pathogens, Int. J. Food Microbiol., 136, 1, 71-4, 2009.

[10]. R.K. Maheshwari, A.K. Singh, J. Gaddipati, R.C. Srimal, Multiple biological activities of curcumin: a short review, Life Sci., 78, 18, 2081-87, 2006.

[11]. P. Anand, A.B. Kunnumakkara, R.A. Newman, B.B. Aggarwal, Bioavailability of curcumin: problems and promise, Mol. Pharm., 4, 6,. 807-18, 2007.

[12]. R.A. Sharma, W.P. Steward, A.J. Gescher, Pharmacokinetics and pharmacodynamics of curcumin, Advances in Experimental Medicine and Biology, 595, 453-70, 2007.

[13]. A. Asaiand, T. Miyazawa, Occurrence of orally administered curcuminoid as glucuronide and glucuronide/sulfate conjugates in rat plasma", Life Sci., 67, 2785-93, 2000.

[14]. M. Sun, X. Su, B. Ding, X. He, X. Liu, A. Yu, H. Lou, G. Zhai, Advances in nanotechnology-based delivery systems for curcumin. Nanomedicine (Lond), 7, 7, 1085-100, 2012.

[15]. F. Kesisoglou, S. Panmai, Y. Wu, Nanosizing-oral formulation development and biopharmaceutical evaluation, Adv. Drug Deliv. Rev., 59, 7, 631-44, 2007.

[16]. R.A.Jr. Freitas, What is nanomedicine?, Nanomedicine: Nanotechnology, Biology, and Medicine, 1, 1, 2-9, 2005.

[17]. A. Sahu, N. Kasoju, P. Goswami, U. Bora, Encapsulation of curcumin in pluronic block copolymer micelles for drug deliveryapplications, $J$. Biomater. Appl., 25, 6, 619-39, 2011.

[18]. L. Zhang, D.L. Parsons, C. Navarre, U.B. Kompella, Development and invitro evaluation of sustained release Poloxamer 407 gel formulation of ceftiofur, $J$. Control Rel., 85, 73-81, 2002.

[19]. A. Higuchi, K. Sugiyama, B.O. Yoon, M. Sakurai, M. Hara, M. Sumita, S. Sugawara, T. Shirai, Serum protein adsorption andplatelet adhesion on pluronicadsorbed polysulfone membranes, Biomaterials, 24, 3235-45, 2003.

[20]. W.J. Jia, J.G. Liu, Y..D Zhang, et al. Preparation, characterization, and optimization of pancreastargeted 5-Fu loaded magnetic bovine serum albumin microspheres, J. Drug Target, 15, 140-45, 2007.

[21]. I.R. Lymam, J.H. Tenery, and R.P. Basson, Correlation between decrease in bacterial load and rate of wound healing, Surg. Gynecol. Obstet, 130, 616-620, 1970.

[22]. T.B.T. Nguyen, L.H. Dang, N.Q. Tran, et al. Green processing of thermosensitive nanocurcuminencapsulated chitosan hydrogel towards biomedical application, Green Processing and Synthesis, vol. 5, pp. 511-520, 2016.

[23]. H.G. Schild, Poly(N-isopropylacrylamide): Experiment, theory and application, Prog. Polym. Sci., 17, 163-249, 1992.

[24]. N.T. Southall, K.A. Dill, A.D.J. Haymet, A view of the hydrophobic effect, J. Phys. Chem. B, 106, 3, 52133, 2002 
[25]. A.A. Barba, M. d'Amore, M. Grassi, S. Chirico, G. Lamberti, G. Titomanlio, Investigation of Pluronic (C) F127-Water solutions phase transitions by DSC and dielectric spectroscopy, J. Appl. Polym. Sci., 114, 2, 68895, 2009.

[26]. SS. Feng, Nanoparticles of biodegradable polymers for new concept chemotherapy, Expert. Rev. Med. Devices, 1, $1,115-25,2004$.
[27]. M.M. Yallapu, M. Jaggi, and S.C. Chauhan, "Curcumin nanoformulations: a future nanomedicine for cancer", Drug Discov. Today, 17, 1-2, 71-80, 2012.

\title{
Hydrogel nanocomposite nhạy nhiệt từ pluronic-grafted gelatin mang nanocurcumin ứng dụng trong chữa lành vết thương
}

\author{
Huỳnh Thị Ngọc Trinh ${ }^{1, *}$, Hà Lê Bảo Trân ${ }^{2}$, Vũ Nguyên Doan², \\ Trần Ngọc Quyên ${ }^{1,3}$ \\ ${ }^{1}$ TraVinh University, \\ ${ }^{2}$ Institute of Applied Materials Science, Vietnam Academy of Science and Technology (VAST), \\ ${ }^{3}$ University of Science, VNU-HCM \\ *Corresponding author: htntrinh99@tvu.edu.vn
}

Ngày nhận bản thảo: 29-05-2017; Ngày chấp nhận đăng: 10-12-2017; Ngày đăng:15-10-2018

Tóm tắt-Curcumin là một hợp chất được chiết xuất từ củ nghệ có nhiều hoạt tính sinh học. Tuy nhiên, tính kỵ nước cao đã làm hạn chế ứng dụng của nó trong dược dụng. Nghiên cứu đưa ra phương pháp điều chế một loại hydrogel nhạy nhiệt có chứa curcumin ở kích thước nano (nCur - PG) để cải thiện đặc tính kém tan trong nước của curcumin. Phương pháp này sử dụng pluronic F127 nhạy nhiệt ghép với gelatin (PG) đóng vai trò như chất hoạt động bề mặt để phân tán và ngăn chặn sự kết tụ của hạt nanocurcumin. Cấu trúc của copolymer PG được xác định bằng phổ cộng hưởng từ hạt nhân ${ }^{1}$ H-NMR. Kích thước hạt nanocurcumin trong hydrogel được xác định bằng kính hiển vi điện tử truyền qua (TEM) và tán xạ ánh sáng động học (DLS) cho thấy hạt nano phân bố từ $1,5 \pm 0,5$ đến $128 \pm 9,7 \mathrm{~nm}$ tùy hàm lượng curcumin sử dụng. Hạt nanocurcumin được phân tán trong dung dịch copolymer PG sẽ tạo thành hệ hydrogel khi nâng nhiệt độ lên 34-35 ${ }^{\circ} \mathrm{C}$. Đường cong nhả thuốc đã chứng minh khả năng nhả chậm curcumin của hydrogel. Hydrogel nanocomposite nhạy nhiệt gelatin - pluronic F127 mang nanocurcumin có tiềm năng là vật liệu y sinh ứng dụng trong lĩnh vực tái tạo mô.

Tù khóa-Nanocurcumin, phương pháp nghiền, gelatin, pluronic F127, hydrogel nanocomposite, thuốc 